\title{
Identifikasi Faktor-Faktor Penumpukan Realisasi Anggaran Belanja Di Akhir Tahun \\ (Studi Kasus Pada Balai Penelitian Dan Pengembangan Lingkungan Hidup Dan Kehutanan Manado)
}

\author{
NINA SUDARWATI ${ }^{1}$, HERMAN KARAMOY ${ }^{2}$, WINSTON PONTOH ${ }^{3}$ \\ 1,2,3Program Magister Akutansi, Fakultas Ekonomi dan Bisnis Universitas Sam Ratulangi \\ ninasudarwati@yahoo.co.id
}

\begin{abstract}
Implementation of the budget is a very important stage in the realization of government programs that have been organized in the National budget. The implementation sometime found difficulties, including the realization of the budget tends to be low in the early years and accumulated at the end of the year. According to Rusqiayati (2014), ideally the realization of the government's budget follows the "S-curve" which is tends to be stable at the beginning of the year, then increased in the mid and stabilized towards the end of the fiscal year. This research aims to identify factors that causing the accumutaed of budget realization in the end of the year at Environment and Forestry Research and Development Institute of Manado. This study is a qualitative case study. The key informants in this research are officers or employees directly involved in financial management, such as the Budget Authority (KPA), Committing Officer (CO), official signing of Warrant Pay (PPSPM), Treasurer, Assistant Treasurer, and Executive Technical Officer (PTK). The results showed that factors that causing the accumulated of budget realization in the end of the year at Environment and Forestry Research and Development Institute of Manado were budget planning, budget execution, procurement of goods/services, and human resources.
\end{abstract}

Keywords: Accumulation, Budget realization, Thematic Analysis

Abstrak Pelaksanaan anggaran merupakan tahap yang sangat peting dalam merealisasikan program dan kegiatan pemerintah yang telah disusun dalam APBN. Dalam pelaksanaan mengalami berbagai kendala, diantaranya realisasi anggaran yang cenderung rendah di awal tahun dan menumpuk di akhir tahun. Menurut Rusqiayati (2014) idealnya, realisasi anggaran pemerintah mengikuti "Kurva S" yaitu cenderung stabil di awal tahun, kemudian meningkat pada pertengahan, dan kembali stabil menjelang akhir tahun anggaran. Penelitian ini bertujuan untuk mengidentifikasi faktor-faktor yang menyebabkan penumpukan realisasi anggaran di akhir tahun pada Balai Penelitian dan Pengembangan Lingkungan Hidup dan Kehutanan Manado. Penelitian ini menggunakan metode kualitatif studi kasus. Informan kunci penelitian ini adalah pejabat atau pegawai yang terlibat langsung dalam pengelolaan keuangan, seperti Kuasa Pengguna Anggaran (KPA), Pejabat Pembuat Komitmen (PPK), Pejabat Penandatangan Surat Perintah Bayar (PPSPM), Bendahara Pengeluaran, Pembantu Bendahara, dan Pelaksana Teknis Kegiatan (PTK). Hasil penelitian menunjukkan bahwa faktor-faktor yang menyebabkan penumpukan realisasi anggaran belanja di akhir tahun pada Balai Penelitian dan Pengembangan Lingkungan Hidup dan Kehutanan Manado yaitu perencanaan anggaran, pelaksanaan anggaran, pengadaan barang/jasa, dan sumber daya manusia.

Kata Kunci : Penumpukan, Realisasi Anggaran Belanja, Analisis Tematik 


\section{Pendahuluan}

Reformasi keuangan negara di Indonesia tahun 2003 ditandai dengan disahkannya undang-undang keuangan negara, yaitu Undang-Undang Nomor 17 Tahun 2003 tentang Keuangan Negara, Undang-Undang Nomor 1 Tahun 2004 tentang Perbendaharaan Negara, dan Undang-Undang Nomor 15 Tahun 2004 tentang Pemeriksaan Pengelolaan dan Tanggungjawab Keuangan Negara. Penetapan Ketiga paket undang-undang keuangan negara tersebut, diharapkan dapat meningkatkan profesionalitas dan keterbukaan, akuntabilitas, serta transparansi dalam pengelolaan keuangan negara sehingga membawa dampak positif terhadap pengelolaan keuangan negara termasuk salah satunya adalah pelaksanaan anggaran.

Anggaran merupakan alat penggerak yang digunakan oleh pemerintah dalam menjalankan suatu roda pemerintahan. Anggaran Pendapatan Belanja Negara (APBN) yang disusun secara sistematis, yang meliputi rencana penerimaan dan rencana pengeluaran untuk satu tahun anggaran, yang disusun oleh pemerintah pusat dan telah disetujui oleh Dewan Perwakilan Rakyat (DPR). APBN merupakan bentuk investasi pemerintah dalam pembangunan perekonomian yang diharapkan mampu mendorong pertumbuhan ekonomi, menciptakan lapangan pekerjaan, dan mengurangi kemiskinan. Karena pentingnya fungsi anggaran dalam perekonomian dan pengertian anggaran tersebut, APBN harus dikelola dengan sebaik-baiknya, mulai dari perencanaan, pelaksanaan, pengawasan sampai dengan pelaporan atau pertanggungjawaban anggaran. Salah satu indikator belanja berkualitas adalah realisasi belanja yang dilaksanakan tepat waktu (Juanda, Halim, Aziz, dan Kaiwai, 2013).

Pelaksanaan anggaran merupakan tahap yang sangat penting dalam merealisasikan program dan kegiatan pemerintah yang telah disusun dalam APBN. Dalam pelaksanaan anggaran mengalami berbagai kendala, diantaranya realisasi anggaran yang cenderung rendah di awal tahun dan menumpuk di akhir tahun.

Menurut Rusqiyati (2014) idealnya, realisasi anggaran pemerintah mengikuti "Kurva S", yaitu cenderung stabil pada awal tahun, kemudian meningkat pada pertengahan dan kembali stabil menjelang akhir tahun anggaran. Pada akhir tahun anggaran terutama bulan Desember semestinya pemerintah hanya melaksanakan sisa-sisa kegiatan dan merapikan administrasi pengelolaan keuangan saja (Rokhman, 2013). Tetapi apa yang terjadi dilapangan menunjukan bahwa realisasi anggaran pemerintah pusat cenderung rendah di awal tahun dan baru mengalami peningkatan pada akhir tahun anggaran.

Pemerintah sudah berupaya untuk mempercepat proses realisasi anggaran antara lain dengan perbaikan kelembagaan, penataan Sumber Daya Manusia (SDM) hingga perbaikan penghasilan/remunerasi untuk meningkatkan kinerja pelayanan terutama yang berhubungan dengan proses realisasi anggaran. Usaha nyata yang telah dilakukan Pemerintah untuk mempercepat realisasi anggaran antara lain diberlakukannya Standard Operating Procedure (SOP) yang lebih baik di Kantor Pelayanan Perbendaharaan Negara (KPPN) dan Kantor Wilayah (Kanwil) Perbendaharaan yang mencakup aspek kecepatan, ketepatan, transparasi dan tanpa biaya, baik dari segi prosedur maupun waktu dengan sentuhan teknologi informasi untuk mendukung pelayanannya, sehingga memperoleh hasil layanan yang lebih efektif dan efisien.

Namun usaha-usaha yang telah dilakukan pemerintah untuk mengatasi penumpukan realisasi anggaran belanja dari tahun ke tahun hasilnya belum memuaskan. Hal ini terlihat dari rendahnya realisasi anggaran belanja di semester pertama dan tingginya realisasi anggaran di semester kedua di Pemerintahan Pusat selama tahun 2011-2015.

Fenomena penumpukan realisasi anggaran di akhir tahun juga terjadi di Balai Penelitian dan Pengembangan Lingkungan Hidup dan Kehutanan Manado (BP2LHK Manado). 
Fenomena ini mencerminkan bahwa di BP2LHK Manado terdapat permasalahan yang terkait dengan pelaksanaan anggaran belanjanya. Penumpukan pembayaran di triwulan IV mencerminkan penyerapan anggaran yang tidak sesuai dengan rencana kegiatan yang telah ditetapkan sebelumnya (Herriyanto, 2012).

Banyak faktor-faktor yang menyebabkan penumpukan realisasi anggaran di akhir tahun antara lain dari perencanaan anggaran, pelaksanaan anggaran, pengadaan barang dan jasa, sumber daya manusia, regulasi pengelolaan anggaran, hingga faktor-faktor internal dari PA. Perencanaan anggaran yang kurang tepat akan menyulitkan dalam hal merealisasikan anggaran dengan demikian akan ada revisi dan menyusun kembali yang tentunya akan membutuhkan waktu ekstra dalam sebuah proses penetapan anggaran. Aspek perencanaan yang tidak matang dalam penentuan anggaran yang akan disajikan akan berdampak pada tidak berjalannya program kerja yang akan dilaksanakan sehingga menjadi salah satu faktor penyebab minimnya penyerapan anggaran (Arif, 2012). Kebijakan yang berubah-ubah serta koordinasi antar instansi/lembaga yang kurang solid juga akan memberikan dampak pada terhambatnya realisasi anggaran belanja. Selanjutnya sumber daya yang menangani proses pelaksanaan anggaran merupakan hal yang menentukan bagi tercapainya realisasi anggaran yang telah ditetapkan. Kualitas SDM dalam hal ini Aparat sipil Negara (ASN) sebagai aparat pengelola keuangan menjadi faktor yang mempengaruhi keterlambatan penyerapan anggaran (Zarinah, Darwanis, dan Abdullah, 2016).

Penelitian tentang penumpukan realisasi anggaran belanja di akhir tahun pada organisasi sektor publik dengan metode penelitian kualitatif belum banyak dilakukan. Pola belanja dengan karakteristik penyerapan yang rendah di semester pertama dan menumpuk pada akhir tahun anggaran berjalan akan mengganggu rencana kinerja kebijakan terhadap perekonomian secara umum (Siswanto dan Rahayu, 2010). Di sisi lain akan berdampak pula pada pertumbuhan ekonomi, penyerapan tenaga kerja, dan pengentasan kemiskinan yang menjadi sasaran kebijakan fiskal secara khusus (Zakiati, 2016).

Tujuan yang ingin dicapai dalam penelitian ini adalah untuk mengidentifikasi faktorfaktor apa saja yang menyebabkan penumpukan realisasi anggaran belanja di akhir tahun pada Balai Penelitian dan Pengembangan Lingkungan Hidup dan Kehutanan (BP2LHK) Manado.

\section{Metode Penelitian}

Penelitian ini menggunakan metode penelitian kualitatif dengan pendekatan studi kasus (case study). Creswell (2015) menjelaskan bahwa penelitian studi kasus adalah pendekatan kualitatif yang penelitiannya mengekplorasi kehidupan nyata, system terbatas kontemporer (kasus) atau beragam system terbatas (berbagai kasus), melalui pengumpulan data yang detail dan mendalam yang melibatkan beragam sumber informasi atau informasi majemuk (pengamatan, wawancara, bahan audiovisual, dokumen, dan berbagai laporan).

Teknik pengumpulan data yang ditempuh dalam penelitian ini adalah melalui wawancara mendalam (in-depth interview), pengamatan/observasi (observation), dan dokumentasi (documentation). Selan-jutnya, uji keabsahan data dalam penelitian kualitatif meliputi uji credibility (validitas internal), transferability (validitas eksternal), dependability (reliabilitas).

Metode analisis data yang dipakai adalah tematik analisis (thematic analysis), yaitu analisis metode kualitatif utuk mengidentifikasi, menganalisis, dan menyajikan pola (tema) dalam data (Braun dan Clarke, 2006). Tahapan analisis tematik dimulai dengan memahami data, melalui pembuatan transkripsi data dan membaca data secara berulang, sampai dengan penyusunan laporan. 
Analisi tematik digunakan untuk memahami fenomena atau gejala sosial dengan lebih menitik beratkan pada gambaran tentang fenomena yang dikaji. Analisis ini memungkinkan peneliti menemukan pola atau tema yang tampil secara acak dalam kumpulan informasi. Dengan menitikberatkan kepada tema tertentu, analisis tematik diharapkan mampu untuk mengetahui secara terperinci dan membuktikan hal yang berkaitan dengan tema tertentu untuk menghasilkan penemuan yang berdasarkan tema.

\section{Hasil dan Pembahasan}

Penelitian ini dilakukan melalui wawancara mendalam (in-denpth interview) dengan informan yang telah dipilih yaitu Kuasa Pengguna Anggaran; Pejabat Pembuat Komitmen Tata Usaha, Sarana Penelitian, dan Pengadaan Barang dan Jasa; Pejabat Pembuat Komitmen Kegiatan Program dan Evaluasi, Data Informasi dan Kerjasama, Kegiatan Penelitian, dan ITTO; Pejabat Penandatangan Surat Perintah Membayar; Bendahara Pengeluaran; Pembantu Bendahara; Pelaksana Teknis Kegiatan Penelitian; dan Pelaksana Teknis Kegiatan Non Penelitian.

Wawancara dilakukan kurang lebih selama 30 menit. Selama proses wawancara, peneliti menggunakan alat bantu alat tulis, laptop, dan alat perekam. Pertanyaan yang diajukan dalam wawancara adalah seputar kendala-kendala yang di hadapi BP2LHK Manado dalam pelaksanaan realisasi anggaran yang menyebabkan penumpukan realisasi anggaran.

Faktor-faktor apa saja yang menyebabkan penumpukan realisasi anggaran belanja di akhir tahun pada BP2LHK Manado, ditemukan empat tema yaitu (1) perencanaan anggaran, (2) pelaksanaan anggaran, (3) pengadaan barang/jasa, (4) Sumber Daya Manusia.

\section{Perencanaan Anggaran}

Ketidaksesuaian antara rencana kegiatan yang diusulkan dengan BP2LHK Manado dengan alokasi anggaran yang ditetapkan dalam DIPA. Hal ini sering kali terjadi karena BP2LHK Manado terkadang tidak menyusun skala prioritas perencanaan kegiatan atau menurut eselon 1 dipandang kegiatan tersebut belum dibutuhkan oleh BP2LHK Manado. Selain itu alokasi DIPA tiap K/L adalah terbatas, sehingga harus digunakan sebaik-baiknya berdasarkan skala prioritas. BP2LHK Manado terkadang lupa dengan usulan kegiatan yang diajukan oleh pelaksana teknis kegiatan, sehingga apabila dalam DIPA ada kegiatan yang tidak diusulkan oleh pelaksana teknis kegiatan, maka pelaksana teknis kegiatan merasa bingung untuk menyusun kembali perencanaan penggunaan dana tersebut.

Dalam penyusunan RKA BP2LHK Manado berdasarkan pagu anggaran yang ditetapkan dalam DIPA. Hal ini tidak sesuai dengan prinsip anggaran berbasis kinerja. Menurut Yunarto (2011), anggaran berbasis kinerja yaitu penyusunan anggaran yang didasarkan pada target kinerja yang ditetapkan terlebih dahulu. Idealnya, kegiatan yang benar-benar dibutuhkan baik jenis maupun jumlahnya dalam rangka memenuhi tugas pokok dan fungsi organisasi.

Penyusunan Rencana Kegiatan Anggaran (RKA) BP2LHK Manado harus sesuai dengan alokasi anggaran yang telah ditetapkan oleh Badan Penelitian Pengembangan dan Inovasi Kementerian Lingkungan Hidup dan Kehutanan. Hal ini sesuai dengan teori keagenan yang dikemukakan Jensen dan Meckling (1976) yang menjelaskan tentang hubungan kontraktual antara pihak yang mendelegasian keputusan tertentu (principal/pemilik/pemegang saham) dengan pihak yang menerima pendelegasian (agent/manajemen). Hubungan kontraktual tersebut mengemukakan antara principal (pemilik) dan agent (manajer) dalam hal mengelola perusahaan, dalam hal ini principal mendelegasikan suatu pertanggungjawaban atas pengambilan keputusan kepada agent untuk melaksanakan suatu kontrak kerja tertentu sesuai dengan kontrak yang telah disepakati. Dalam teori keagenan (agency theory)

Dalam perencanaan anggaran di BP2LHK Manado masih terjadi kesalahan penggunaan akun belanja dalam DIPA. Hal ini terjadi karena kurang telitinya petugas perekam RKA-KL 
maupun petugas penelaah DIPA. Kesalahan tersebut harus diperbaiki terlebih dahulu melalui proses revisi DIPA agar realisasi anggaran dapat dilaksanakan. Kendala administrasi dapat berupa kesalahan pemakaian akun belanja dan penepatan sumber dana PNBP dan RM. Hal tersebut dapat terjadi karena kurang teliti petugas perekam RKA-KL BP2LHK Manado maupun petugas penelaah DIPA. Hasil penelitian ini juga didukung oleh penelitian yang dilakukan oleh Miliasih (2012) bahwa keterlambatan dalam realisasi anggaran dapat disebabkan oleh kesalahan dalam dokumen DIPA, sehingga DIPA tidak sesuai dengan kebutuhan. Penyebab kesalahan contohnya adalah kesalahan penggunaan akun dikegiatan dalam DIPA.

Menurut Yunarto (2011), perencanaan anggaran yang mengakibatkan rendahnya penyerapan anggaran diantaranya: (1) Perencanaan kegiatan yang tidak sesuai dengan kebutuhan; (2) Data pendukung yang tidak lengkap pada saat penyusunan anggaran; (3) Salah penentuan akun sehingga perlu merevisi dokumen anggaran; (4) Penyusunan pagu anggaran tidak sesuai harga pasar; (5) Term of Reference (TOR) salah atau tidak lengkap; (6) Rencana Anggaran Belanja (RAB) tidak sesuai dengan satuan biaya; (7) Tidak adanya formulasi rencana penarikan anggaran.

\section{Pelaksanaan Anggaran}

Berdasarkan hasil wawancara penelitian, ada beberapa kendala dalam pelaksanaan anggaran di BP2LHK Manado, antara lain (1) jadwal kegiatan internal BP2LHK Manado; (2) jadwal instansi terkait/lain; (3) kegiatan penelitian yang ketergantungan dengan lingkungan (musim); (4) peraturan tata cara pembayaran sumber dana PNBP yang belum dapat dipastikan; (5) kurang disiplin dalam mengikuti jadwal kegiatan; (6) kegiatan yang belum dapat dilaksanakan karena memerlukan revisi DIPA; (7) adanya kebijakan pemerintah pusat.

Belum adanya perencanaan pelaksanaan kegiatan internal BP2LHK Manado. Dalam pelaksanaan kegiatan berdasarkan selesainya kegiatan yang menjadi unsur pendukung kegiatan tersebut dan berdasarkan perintah KPA. Belum adanya perencanaan kegiatan dan perjalananan dinas pegawai/pejabat, baik pelaksanaan kegiatan internal BP2LHK Manado maupun rencana perjalanan dinas yang terkait dengan kegiatan/undangan dari instansi lain. Kondisi tersebut merupakan kendala dalam pelaksanaan realisasi anggaran di BP2LHK Manado. Hasil penelitian ini juga didukung oleh penelitian yang di lakukan oleh Miliasih (2012), mengatakan bahwa keterlambatan realisasi belanja barang untuk belanja perjalanan dinas dipengaruhi oleh jadwal kegiatan internal satker dan jadwal kegiatan intansi lain/terkait.

Kegiatan penelitian di BP2LHK Manado berupa penanaman yang ketergantungan terhadap lingkungan yaitu musim hujan. Sehingga kegiatan tersebut belum dapat dilaksanakan apabila belum adanya tanda-tanda musim hujan. Penundaan pelaksanaan kegiatan ini mengakibatkan terhambatnya realisasi anggaran belanja di BP2LHK Manado. Hasil pembahasan di atas sejalan dengan penelitian yang dilakukan oleh Hasan (2016), yang menghasilkan faktor ancaman penyebab rendahnya rendahnya penyerapan anggaran belanja adalah adanya pengaruh musim terhadap kegiatan penelitian.

Pelaksanaan kegiatan di BP2LHK Manado dapat dilakukan apabila sudah tersedianya sumber dana. Dimana sumber dana PNBP dapat direalisasikan berdasarkan aturan maksimal pencairan sumber dana PNBP. Hal ini sejalan dengan teori implementasi kebijakan Edward III (1980), menurutnya sumber daya adalah faktor penting untuk implementasi kebijakan. Kegiatan dapat dilakukan karena adanya fasilitas-fasilitas pendukung yang dapat dipakai seperti dana dan sarana-prasarana Dalam pelaksanaan anggaran BP2LHK Manado dipengaruhi oleh adanya hal-hal yang memaksa BP2LHK Manado untuk menunda melakukan realisasi anggaran karena adanya aturan tentang petunjuk pencairan anggaran yang bersumber dari dana khusus seperti dana PNBP dan hal ini sesuai dengan teori institutional 
isomorphism terutama coercive isomorphism. Seperti yang diungkapkan DiMagio dan Powel (1983) bahwa di dalam organisasi publik, institutional isomorphism dapat terjadi karena adanya tekanan institusional yang diakibatkan oleh coercive isomorphism, mimetic isomorphism, atau normative isomorphism. Realisasi anggaran BP2LHK Manado dipengaruhi oleh tekanan (paksaan) peraturan maupun kekuasaan (coercive isomorphism), meniru atau mengikuti organisasi publik lain (mimetic isomorphism) atau adanya kesadaran bahwa realisasi anggaran tersebut harus dilakukan sebaik mungkin tanpa menunda apapun agar memperoleh manfaat yang optimal (normative isomorphism).

Pelaksanaan kegiatan di BP2LHK Manado tidak berdasarkan lampiran III DIPA atau POK. Pelaksanaan kegiatan berpedoman pada dokumen RKA dan instruksi oleh KPA. Lampiran III DIPA belum berperan sesuai fungsinya, dan lebih bersifat hanya sebagai kelengkapan administratif dalam pengesahan DIPA. Kurang disiplin mengikuti jadwal kegiatan yang sudah ada dalam lampiran lembar III mengakibatkan terhambatnya pelaksanaan anggaran. Penumpukan pembayaran di triwulan ke IV mencerminkan penyerapan anggaran yang tidak sesuai dengan rencana kegiatan yang telah ditetapkan (Herriyanto, 2012). Revisi anggaran disebabkan oleh perencanaan pengalokasian anggaran yang kurang baik. Revisi anggaran sepanjang tidak mengubah DIPA cukup dilakukan oleh pengguna anggaran, akan tetapi apabila revisi anggaran mengubah dokumen DIPA memerlukan waktu yang cukup panjang untuk merevisinya. Hal tersebut karena terdapat dua pintu dalam proses revisi pada Kementerian Keuangan yaitu proses revisi pada Direktorat Jenderal Anggaran dan pada Direktorat Jenderal Perbendaharaan. Sehingga kegiatan belum dapat dilaksanakan karena menunggu revisi DIPA. Kondisi tersebut menyebabkan keterlambatan realisasi anggaran di BP2LHK Manado. Herriyanto (2012), menjelaskan revisi anggaran menyebabkan keterlambatan penyerapan anggaran karena pelaksanaan anggaran harus menunggu revisi anggaran selesai.

Adanya kebijakan pemerintah pusat terkait pemotongan anggaran dan self blocking mengakibatkan pelaksanaan kegiatan harus disusun kembali menurut kebutuhan yang disesuaikan kembali berdasarkan anggaran belanja setelah pemotongan dan self blocking. Adanya kebijakan pemerintah pusat terkait pemotongan anggaran dan self blocking mengakibatkan BP2LHK Manado harus menyusun kembali perencanaan pelaksanaan kegiatan dan SDM yang terlibat di dalamnya berdasarkan anggaran hasil pemotongan dan self blocking. Begitu juga dengan adanya nomenklatur Kementerian Kehutanan mengakibatkan berubahnya stuktur organisasi dan anggaran kementerian. Kondisi tersebut mengakibatkan berubahnya sruktur organisasi dan anggaran di BP2LHK Manado yang merupakan unit pelaksana teknis Kementerian Kehutanan. Sehingga kegiatan belum bisa direalisasikan sebelum adanya perintah dari pusat. Hal ini sejalan dengan pendapat Edward III (1980), menurutnya struktur organisasi yang bertugas mengimplementasikan kebijakan memiliki pengaruh yang signifikan terhadap implementasi kebijakan. Struktur organisasi yang terlalu panjang akan cenderung melemahkan pengawasan dan menimbulkan red-tape, yakni prosedur birokrasi yang rumit dan kompleks serta menyebabkan aktivitas organisasi tidak fleksibel. Demikian halnya dengan hasil penelitian yang dilakukan oleh Hasan (2016), yang menghasilkan bahwa faktor ancaman optimalisasi penyerapan anggaran adalah adanya kebijakan pemerintah pusat terkait pemotongan anggaran dan self blocking.

\section{Pengadaan Barang dan Jasa}

Sesuai Peraturan Presiden (Perpres) Nomor 54 Tahun 2010 sebagaimana telah diubah terakhir dengan Perpres Nomor 4 Tahun 2015 tentang Pengadaan Barang/Jasa Pemerintah, pengadaan barang/jasa adalah kegiatan untuk memperoleh barang/jasa oleh K/L/SKPD/institusi yang prosesnya dimulai dari perencanaan kebutuhan sampai diselesaikannya seluruh kegiatan untuk memperoleh barang/jasa. Berdasarkan wawancara 
yang dilakukan dengan informan penelitian, ada beberapa permasalahan terkait dengan pengadaan barang/jasa yang dapat menghambat proses realisasi anggaran pada BP2LHK Manado, yaitu (1) kurangnya pejabat pengadaan yang mempunyai sertifikat; (2) kekhawatiran PPK dan pejabat pengadaan terhadap penegak hukum dan pemeriksa; (3) terlambatnya proses pelelangan; (4) kegagalan pelelangan; (5) pekerjaan belum dapat dilaksanakan karena memerlukan revisi Rancangan Umum Pengadaan (RUP) terlebih dahulu.

Sesuai dengan Perpres Pengadaan Barang/Jasa Pemerintah, semua pejabat pengadaan dan PPK wajib memiliki Sertifikat Keahlian Pengadaan Barang/Jasa yang diterbitkan oleh Lembaga Kebijakan Pengadaan Barang/Jasa (LKPP). Pemberian sertifikat tersebut sangat selektif karena hanya pegawai yang mempunyai kompetensi dan kemampuan profesi di bidang pengadaan barang/jasa saja yang akan diberi sertifikat dengan dibuktikan pegawai tersebut lulus dalam ujian pengadaan barang/jasaDikarenakan sulitnya mendapatkan sertifikat tersebut, di BP2LHK Manado hanya mempunyai tiga pegawai yang telah memiliki sertifikat. Disamping menjalankan tugasnya sebagai pejabat pengadaan pegawai tersebut juga masih harus mengerjakan pekerjaan sesuai tupoksinya. Apabila ada pekerjaan pengadaan yang besar, kemungkinan beban kerja pejabat tersebut akan semakin berat. kurangnya pejabat pengadaan yang mempunyai sertifikat pengadaan mengakibatkan lambatnya proses pengadaan barang dan jasa, sehingga menghambat realisasi anggaran belanja di BP2LHK Manado. Terbatasanya SDM bersertifikat sehingga adanya rangkap tugas dalam kegiatan. Panitia yang ada tidak sebanding dengan jumlah pekerjaan barang/jasa dalam satu tahun anggaran (Miliasih, 2012). Demikian halnya yang dikemukakan oleh Edward III (1980), sumber daya manusia yang tidak memadai (jumlah dan kemampuan) berakibat tidak dapat dilaksanakannya kebijakan secara sempurna serta tidak mampu melakukan pengawasan dengan baik. Jika jumlah staf pelaksana kebijakan terbatas, maka hal yang harus dilakukan adalah meningkatkan kemampuan/keterampilan para pelaksana untuk melakukan penerapan kebijakan. Untuk itu, perlu adanya manajemen SDM yang baik agar dapat meningkatkan kinerjanya.

Pejabat pengadaan dan PPK merasa khawatir terhadap aparat penegak hukum yang sedang gencar-gencarnya memerangi korupsi, seperti Komisi Pemberantasan Korupsi (KPK) dan Kejaksaan, maupun aparat pemeriksa, seperti BPK, BPKP, atau Inspektorat Jenderal. Ketakutan tersebut dapat mengakibatkan pejabat pengadaan dan PPK terlalu berhati-hati dalam mengambil keputusan merealisasikan belanja modal barang/jasa dan lambatnya proses pengadaan. Hasil penelitian ini juga mendukung penelitian yang dilakukan oleh Sinaga (2016), yang mengungkapkan rendahnya penyerapan anggaran terjadi akibat adanya ketakutan yang berlebihan dari masing-masing aparatur di berbagai institusi terkait dengan penggunaan anggaran.

Tidak ada perencanaan pelaksanaan pengadaan barang dan jasa, mengakibatkan terlambatnya waktu pelaksanaan dan proses lelang pengadaan barang dan jasa. Keterlambatan proses pelelangan akan berdampak pada proses penyelesaian fisik pekerjaan, baik secara kualitas maupun keterbatasan waktu penyelesaian karena mendekati akhir tahun, sehingga proses pengajuan pembayaran, mulai dari pembayaran uang muka sampai dengan pembayaran retensi dapat terlambat. Arif (2012), lambatnya proses lelang ditambah lagi konflik-konflik yang terjadi selama proses tender berlangsung semakin memperparah lamanya waktu yang dibutuhkan untuk implementasi anggaran.

Adanya pelelangan yang gagal, yaitu apabila pelelangan tidak memperoleh pemenang lelang yang akan melaksanakan pekerjaan yang diakibatkan dari ketidaksanggupan rekanan dalam memenuhi persyaratan pekerjaan. Akibatnya pelelangan harus dimulai dari awal dan ini hal akan membutuhkan waktu lama lagi, sementara waktu pencairan anggaran semakin sedikit, sehingga kemungkinan penumpukan realisasi anggaran di akhir tahun semakin besar. 
Ketidaksesuaian besarnya anggaran dalam DIPA dengan RUP yang telah disusun, sehingga harus dilakukan revisi RUP agar pengadaan barang/jasa dapat dilaksanakan. Kondisi tersebut mengakibatkan pelaksanaan pengadaan barang/jasa di BP2LHK Manado terealisasi setelah semester II.

Pengadaan barang/jasa belum dapat dilaksanakan karena memerlukan revisi Rancangan Umum Pengadaan (RUP) terlebih dahulu. ketidaksesuaian anggaran belanja modal dengan RUP yang menjadi acuan BP2LHK Manado untuk melaksanakan pengadaan barang dan jasa maka KPA harus menyusun RUP kembali. Dalam Perpres nomor 4 tahun 2015 menjelaskan bahwa apabila ada perubahan RUP barang dan jasa KPA harus mengumumkan kembali RUP website BP2LHK Manado, papan pengumuman resmi untuk masyarakat, dan Portal Pengadaan Nasional melalui Layanan Pengadaan Secara Elektronik (LPSE).

\section{Sumber Daya Manusia}

Menurut Nawawi (2007), sumber daya manusia adalah manusia yang bekerja di lingkungan suatu organisasi (disebut juga personil, tenaga kerja, pekerja, atau karyawan). Dalam penelitian ini menemukan beberapa permasalahan terkait sumber daya manusia BP2LHK Manado yang mengelola keuangan antara lain yaitu: (1) kurangnya jumlah pegawai; (2) pola mutasi pegawai; (3) adanya perangkapan jabatan; (4) pengelola anggaran tidak ditempat, (5) komunikasi antar pengelola anggaran; (6) SDM kurang kompeten.

Pelaksanaan kegiatan di PB2LHK Manado dapat berjalan dengan baik, harus didukung dengan jumlah pegawai yang ideal. Sampai saat ini jumlah pegawai di BP2LHK Manado masih kurang ideal. Kekurangan jumlah pegawai khusunya yang menangani keuangan di BP2LHK Manado dapat menghambat proses realisasi anggaran. Pendapat Edward III (1980), menurutnya komponen sumber daya meliputi jumlah staf, keahlian dari para pelaksana, informasi yang relevan serta cukup untuk menerapkan kebijakan dan pemenuhan sumbersumber terkait dalam pelaksanaan kebijakan, adanya wewenang yang menjamin bahwa kebijakan dapat diarahkan sebagaimana yang diharapkan serta adanya fasilitas-fasilitas pendukung yang dapat dipakai untuk melakukan kegiatan seperti dana dan sarana prasarana

Kekuarangan pegawai tersebut selanjutnya dapat menyebabkan adanya perangkapan jabatan agar seluruh pekerjaan di BP2LHK Manado dapat berjalan dengan baik. Apabila orang yang ditempatkan tidak tepat pada jabatan-jabatan yang tersedia akan memberikan pengaruh yang negatif terhadap perkembangan organisasi antara lain: para pegawai akan merasa frustasi dalam bekerja, para pegawai akan bekerja lamban dan hasil kerjanya kurang bermutu (Arif, 2012).

Pola mutasi pegawai juga bisa berakibatnya keterlambatan realisasi anggaran. Pegawai atau pejabat yang menangani keuangan di BP2LHK Manado apabila dipindahkan ke seksi atau kantor lain, maka diperlukan pengganti pegawai atau pejabat tersebut. Menurut pendapat Sinaga (2016), dengan pergantian SDM atau karyawan di masing-masing kementerian-lembaga membuat system aplikasi rawan blank yang berdampak pada rendahnya penyerapan anggaran kementerian-lembaga. Oleh karena itu, perlunya kaderisasi pegawai pengelola anggaran, untuk antisipasi ada mutasi pegawai agar tidak menghambat pelaksanaan realisasi anggaran belanja di BP2LHK Manado.

Pejabat pengelola anggaran yang tidak ada di kantor, berakibat terlambatnya realisasi anggaran di BP2LHK Manado. Apabila PPK tidak ada di kantor, menyebabkan pengesahan dokumen pendukung realisasi anggaran terhambat.

Komunikasi antar pengelola anggaran yang kurang baik juga dapat mengakibatkan terhambatnya proses realisasi anggaran di BP2LHK Manado. Sejalan dengan Edward III (1980), menurutnya komunikasi dalam organisasi merupakan suatu proses yang amat 
kompleks dan rumit. Sumber informasi yang berbeda dapat melahirkan interpretasi yang berbeda pula. Agar implementasi berjalan efektif, siapa yang bertanggungjawab melaksanakan sebuah keputusan harus mengetahui apakah sebuah implementasi dapat terlaksana.

Menurut Arif (2012), ketidak saling komunikasian antar anggota organisasi dapat mengakibatkan terhambatnya organisasi dalam pengimplementasian program kerja pemerintah. Untuk itu perlunya pimpinan BP2LHK Manado untuk menata ulang alur komunikasi antar pengelola anggaran, agar semua informasi dan program kerja yang akan dilaksanakan bisa terealisasi dengan baik dan lancar sesuai dengan perencanaan dan target yang telah dibuat.

SDM kurang kompeten juga bisa berakibat terlambatnya realisasi anggaran belanja. Kompetensi pegawai mutlak diperlukan agar dalam pengelolaan anggaran dapat dilaksanakan. Kompetensi merupakan suatu karakteristik dari seseorang yang memiliki ketrampilan (skill), pengetahuan (knowledge), dan kemampuan (ability) untuk melaksanakan suatu pekerjaan (Hevesi, 2005). Bila sekelompok karyawan dan atasannya mempunyai kinerja yang baik, maka akan berdampak pada kinerja organisasi baik pula, dimana kualitas SDM sangat menentukan dalam pelaksanaan dan pencapaian tujuan organisasi dengan peningkatan kinerja yang sangat diharapkan (Arsyiati, Darwanis, dan Djalil, 2008).

\section{Penutup}

Kesimpulan penelitian adalah BP2LHK Manado dalam pelaksanaan realisasi anggaran terdapat empat faktor yang penghambat realisasi anggaran yaitu faktor perencanaan anggaran, faktor pelaksanaan anggaran, faktor pengadaan barang dan jasa, dan faktor sumber daya manusia.

Saran yang dapat diberikan dari penelitian ini: (1) Dalam penyusunan anggaran harus menyiapkan rencana kegiatan, kemudian mengalokasikan anggaran untuk setiap program dan kegiatan berdasarkan prioritas secara efektif, efisien dan dapat diukur hasilnya, (2) Pengawasan (supervision) Kuasa Pengguna Anggaran dan PTK perlu ditingkatan dalam hal tertib pelaksanaan, pertanggungjawaban, dan pelaporan, (3) Perlunya perencanaan anggaran yang realistis dan memperhatikan Bagan Akun Standar (BAS) dan standar harga dalam perencanaan anggaran, (4) Penyusunan POK seharusnya melibatkan setiap pelaksana teknis kegiatan, (5) Penyusunan RUP sebaiknya disusun sebelum tahun anggaran berjalan, (6) Mengalokasikan anggaran belanja yang bersumber dana PNBP secara efektif, (7) Pemberian penghargaan (reward) dan sanksi (punishment) kepada pengelola dan pelaksana kegiatan sesuai dengan ketentuan.

\section{Daftar Pustaka}

Arif, Emkhad, 2012. Identifikasi Faktor-Faktor Penyebab Minimnya Penyerapan Anggaran Pendapatan dan Belanja Daerah (APBD) Kabupaten/Kota di Provinsi Riau Tahun 2011. Jurnal Ekonomi, Manajemen, dan Akuntansi I. Vol. 11. No. 2. Hal. 41-61.

Arsyiati, Darwanis, dan Djalil A. Muslim. 2008. Pengaruh Kualitas Sumber Daya Manusia Dalam Pengelolaan Keuangan Terhadap Kualitas Pertanggungjawaban Keuangan PNBP Dalam Upaya Meningkatkan Kinerja Instansi Pada Universitas Syiah Kuala. Jurnal Telaah Riset Akuntansi. Vol. 1. No. 1. Hal. 29-49.

Braun, Virginia dan Clarke, Victoria. 2006. Using Thematic Analysis in Psychology. Qualitative Research in Psychology, 3 (2). pp. 77-101.

Cresswell, John Well. 2010. Research Design: Qualitative, Quantitative, And Mixed Method Approaches. Third Edition. Thousand Oaks. California. 
DiMaggio, Paul J. dan Powell, Walter W. 1983. The Iron Cage Revisited: Institutional Isomorphism and Collective Rationality in Organizational Fields. American Sociological Review 48(2): 147-160.

Edwards, George C. III. 1980. Implementing Public Policy. Washington DC: Congressional, Quarterly Press.

Hasan, Arif. 2016. Strategi Maksimalisasi Penyerapan Anggaran Belanja Triwulan III Pada Balai Penelitian dan Pengembangan Lingkungan Hidup dan Kehutanan Manokwari. Tesis. Program Studi Manajemen Pembangunan Daerah. Institut Pertanian Bogor.

Herriyanto, Hendris. 2012. Faktor-Faktor yang Mempengaruhi Keterlambatan Penyerapan Anggaran Belanja pada Satuan Kerja Kementerian/Lembaga di Wilayah Jakarta. Tesis. Program Studi Perencanaan dan Kebijakan Publik Universitas Indonesia Jakarta.

Hevesi, G. Alan. 2005.

Standards for Internal Control in New York State Government. www.ose.state.ny.us

Jensen,M., and Meckling, W. 1976. Theory of the firm: Managerial behavior, agency costs, and ownership structure. Jurnal of Financial Economics, 3: 305-306.

Miliasih, Retno. 2012. Analisis Keterlambatan Penyerapan Anggaran Belanja Satuan Kerja Kementerian Negara/Lembaga TA 2010 di Wilayah Pembayaran KPPN Pekanbaru. Tesis. Program Magister Perencanaan dan Kebijakan Publik Universitas Indonesia. Jakarta.

Rokhman, A. 2013. Membedah Permasalahan Anggaran, Meraih Solusi Strategis. Kanwil Ditjen Perbendaharaan Provinsi D.I. Yogyakarta. 23 Desember 2013. Tersedia di http://kwldjpb-jogja.net/berita/membedah-permasalahan-anggaran-meraih-solusistrategis/, diakses pada 2 November 2016

Rusqiati, D. W. 2014. Realisasi Penyerapan Anggaran Pemprov 2013 di Bawah Target. Metrotvnews. $24 \quad$ Februari 2014.2 Tersedia di http://microsite.metrotvnews.com/metrotvnews/read/2014/02/24/2/218445/Realisas i-Penyerapan-Anggaran-Pemprov-di-Bawah-target.html

Sinaga, Erward James. 2016. Analisis Rendahnya Penyerapan Anggaran Kementerian/Lembaga (K/L) Dan Pemerintah Daerah. Pusat Pengkajian dan Pengembangan Kebijakan Balitbang Hukum dan HAM Kementerian Hukum dan HAM RI. Vol. 5, No. 2, Agustus 2016.

Yunarto, I. 2011. Memahami Proses Penganggaran untuk Mendorong Optimalisasi Penyerapan Anggaran.

Yogyakarta: Paris Review. 